\begin{tabular}{l|c|c}
\hline $\begin{array}{l}\text { ISSN: 0001-5113 } \\
\text { AADRAY }\end{array}$ & ACTA ADRIAT., & ORIGINAL SCIENTIFIC PAPER \\
\hline \hline
\end{tabular}

\title{
Wind storminess in the Adriatic Sea in a climate change scenario
}

\author{
Davide BONALDO ${ }^{1 *}$, Edoardo BUCCHIGNANI ${ }^{2,3}$, Antonio RICCHI ${ }^{4}$ \\ and Sandro CARNIEL ${ }^{1}$ \\ ${ }^{1}$ Institute of Marine Sciences, National Research Council (CNR-ISMAR), Venice, Italy \\ ${ }^{2}$ Regional Models and Geo-Hydrogeological Impacts Division, Centro Euro-Mediterraneo sui \\ Cambiamenti Climatici (CMCC), Capua, Italy \\ ${ }^{3}$ Meteorology Laboratory, Centro Italiano Ricerche Aerospaziali (CIRA), Capua, Italy \\ ${ }^{4}$ Università Politecnica delle Marche, Ancona, Italy \\ *Corresponding author, e-mail: davide.bonaldo@ve.ismar.cnr.it
}

\begin{abstract}
In this work we assess the quality of the wind fields provided over the Adriatic Sea by the Regional Climate Model COSMO-CLM with reference to a control (CTR) period from 1971 to 2000 and to a future period from 2071 to 2100 under IPCC RCP 8.5 scenario (SCE), focusing on the implications for wave climate characterisation. Model skills have been assessed by comparing CTR results in terms of gross statistical properties and storm features against wind data from coastal observatories along the whole Italian Adriatic coast, showing a satisfactory capability of capturing the main features of mean observed seasonal variability. Significant achievements with reference to existing climatological models have been observed especially in terms of wind directionality, with unprecedented performances in reproducing the bimodal dominance of Bora (from northeast) and Sirocco (from southeast) in the northern basin, and the typical patterns of Bora jets flowing from the mountain ridges enclosing the Adriatic Sea on its eastern side. Future projections generally confirm the tendency to a decreasing energy trend envisaged by previous studies, with a more marked effect for extreme events in the northern basin.

Based on the comparison between climatological wind fields and the results of a SWAN wave model run forced by COSMO-CLM, we also define and test a criterion for a rapid identification of some relevant case studies for dedicated wave modelling experiments, without the need of running entire climatological wave simulations. This permits to focus the analysis of climatological oceanographic extreme events to a limited number of selected cases, allowing remarkable saving of computational effort especially if an ensemble approach is desired
\end{abstract}

Key words: wind climate, climatological modelling, wave modelling inputs 


\section{INTRODUCTION}

The increasing awareness of the hazards related to climate change impacts on coastal zones and the need for decadal to centennial adaptation or mitigation strategies (SLOTT et al., 2006; TOL et al., 2008; NICHOLLS, 2011) have been driving the development and implementation of several climatological modelling efforts at global to regional scale. This allowed to draw some estimates on possible change in different features of meteo-oceanic dynamics, such as temperature and precipitation patterns (GIORGI et al., 2004), multi-annual fluctuations (VECCHI \& WITTEMBERG, 2010), wave storminess and surge hazard (LIONELLO et al., 2008; BENETAZZO et al., 2012; CONTE et al., 2014), as well as the effectiveness and implications of downscaling techniques (BELLAFIORE et al., 2012). Together with sea level rise estimates, the identification of some evolution trends in the drivers of coastal morphodynamics, such as wind and wave climate, is highly desirable. Although necessary for providing a sound framework for the development of different long-term numerical modelling approaches for coastal processes prediction and management (CHINI \& STANSBY, 2012; VAN MAANEN et al., 2015; BONALDO et al., 2015), this is still a relatively underrated activity. An appropriate evaluation of the meteo-marine climate is also crucial for predicting possible impacts on the mechanisms triggering large-scale circulation and deep sea ventilation, such as open sea convection (KILLWORTH, 1983; BENSI et al., 2013) and dense water formation on continental shelves and downflow across the continental margin (IVANOV et al., 2004; CANALS et al., 2006; BENETAZZO et al., 2014). These processes, although relevant for circulation at the mesoscale and above, can depend on meteooceanic processes characterised by strong intensity and sharp spatial gradients (VILIBIĆ \& SUPIĆ, 2005; MIHANOVIĆ et al., 2013; RICCHI et al., 2016) and be strongly controlled by small-scale topographic features such as orographic gaps, therefore requiring a high spatial resolution in order to be completely described (SIGNELL et al., 2005).

Although some experiments towards an ocean-atmosphere coupled approach in cli- matological studies have been set up (e.g. the EBU-POM regional climate model proposed by DJURDJEVIĆ \& RAJKOVIĆ, 2010), a full coupling among wave, ocean and atmosphere dynamics (e.g. ZAMBON et al., 2014; CARNIEL et al., 2016) is presently unusual over this time scale in high-resolution models. Often representing the first stage of the climatological analysis, model datasets providing atmospheric information are generally sufficiently easy to source. In turn, the evaluation of climatologies for sea state descriptors from numerical wave models generally requires a further step with multi-decadal runs at a high computational cost, especially when an ensemble modelling strategy is desired. Moreover, this cost can be barely justified when the analysis is focused on the description of extreme events, which in fact are the reference in coastal risk management issues and in the development of protection and mitigation strategies. A possible alternative strategy consists of relying on regional downscaling of atmospheric modelling systems to identify sets of relevant events for the description of a given meteo-oceanic process. Once identified, these events can be further investigated via dedicated simulations with the possibility of increasing the resolution and the degree of complexity of the model framework, potentially adopting an ensemble approach.

In this direction, the present study explores the potential of the high-resolution implementation of the Regional Climate Model (RCM) COSMO-CLM (ROCKEL et al., 2008), over the Adriatic Sea (BUCCHIGNANI et al., 2016). This domain is an epicontinental system located in the northeastern Mediterranean basin and encompassed by the Apennines to the West, by the Alps to the North and by the Dinarides to the East. The Adriatic Sea is is a valuable test site for a broad range of meteo-oceanic applications, due to the peculiar processes taking place there and largely controlled by wind dynamics, such as dense water formation (SUPIĆ \& ORLIĆ, 1999; VILIBIĆ \& SUPIĆ, 2005; BENETAZZO et al, 2014) and the occurrence and possible co-existence of swell and generative sea states. In particular, swell seas are mostly dominated by Sirocco, a warm and humid southeasterly wind, while energetic gen- 
erative seas are controlled by Bora, a cold and gusty northeasterly wind blowing in jets from orographic gaps (CAVALERI et al., 1989; ORLIĆ et al., 1994; KUZMIĆ et al., 2013). Furthermore, the combination of morphological setting and strong anthropic pressure along the coasts, especially in the northern and central basins (TORRESAN et al., 2012; ACCIARRI et al., 2016), together with a longstanding coastal sediment deficit (NELSON, 1970), bestow paramount importance to the issue of long-term coastal planning and protection in this area. This work aims at:

1) Assessing the reliability, and improvements with respect to previous state of the art, of the wind estimates provided by the RCM COSMO-CLM at high-resolution, with a focus on the peculiar characteristics of the Adriatic Sea;

2) Identifying the main features of the present wind climate over the Adriatic Sea and expected modifications in a climate change scenario of utmost severity, with special care to the highly energetic events and their possible implications in terms of kinetic energy injection into the ocean surface layers and wave generation;

3) Assessing the possibility of using high-resolution COSMO-CLM model results as a proxy for the identification of severe wave storm that may strongly impact the Adriatic coasts.

\section{MATERIALS AND METHODS}

Climatological projections of atmospheric variables have been obtained with the RCM COSMO-CLM (ROCKEL et al., 2008). This is the climate version of the operational non-hydrostatic mesoscale weather forecast model COSMOLM (STEPPELER et al., 2003), developed by the German Weather Service (DWD). Likewise its operational counterpart, COSMO-CLM solves the non-hydrostatic formulation of the NavierStokes equations for a compressible flow assuming a hydrostatic base state at rest. The atmosphere is treated as a multicomponent fluid (dry air, water vapour, liquid and solid water) for which the perfect gas equation holds and it is subjected to the gravity and the Coriolis forces. The unresolved subgrid-scale phenomena are taken into account in a statistical manner through a number of parameterizations. While COSMOLM is driven by operational global weather forecast models, COSMO-CLM forcings are provided by the Global Climate Model CMCCCM (SCOCCIMARRO et al., 2011). COSMO-CLM has been validated within several projects such as PRUDENCE (CHRISTENSEN et al., 2007), and its response has been found to be in the sarne range of accuracy as other RCMs, resolving similar scales. The RCM COSMO-CLM was used to perform a climate simulation over Italy, employing a spatial resolution of about $8 \mathrm{~km}$, over the period 1971-2100 according with the IPCC RCP8.5 scenario (MOSS et al., 2010), predicting a generalized warming and a predominant reduction in precipitation, especially in summer (BUCCHIGNANI et al., 2016; ZOLLO et al., 2016).

Initial and boundary conditions were provided by the coupled atmosphere-ocean general circulation model CMCC-CM (SCOCCIMARRO et al., 2011). In this work, datasetes referred to two different periods have been extracted for the analysis, namely under Control (CTR, 19712000 ) and climate change Scenario (SCE, 20712100) conditions.

Climatological wind fields from COSMOCLM simulations were used as a forcing for two 30-years runs carried out within the phase-averaged wave model SWAN (Simulating WAves Nearshore, BOOIJ et al., 1999) for describing spectral properties of sea states in the Adriatic basin. Model grid horizontal resolution ranges from approximately $7 \mathrm{~km}$ along the central and easternmost reaches of the Adriatic Sea down to $2 \mathrm{~km}$ along the Italian coasts (Fig. 1). The bathymetry results from a merging of high-resolution multibeam data collected during several oceanographic surveys in the northern basin and along the Southern Adriatic margin (FOGLINI et al., 2016; BONALDO et al., 2016), interpolated on the domain grid. Sea level rise in the climate change scenario was taken into account by increasing the water depth by $0.70 \mathrm{~m}$ based on estimates provided by ANTONIOLI et al. (2017). Following the established implementation by BENETAZZO 
et al. (2013 for a thorough validation; see also BENETAZZO et al., 2014 for another application), the wave fields were represented by components propagating in 36 evenly spaced directions and discretised into frequencies geometrically distributed between 0.05 and $0.5 \mathrm{~Hz}$, with $360 \mathrm{~s}$ time step. Calm conditions were prescribed in the initialization of each run and wave radiation was allowed out of the southern boundary, while no waves were allowed to enter the domain.

\section{Wind data from coastal observatories}

Wind data relative to present conditions for CTR run evaluation were retrieved from the Rete Mareografica Nazionale (http://www.mareografico.it/), a national network collecting tide, waves and wind data along the Italian coasts. Most of the data sets span the 2010-2015 period (Table 1), covering an integer number of years in order to preserve the significance of annual statistics.

Although such a relatively short period may not be fully sufficient for drawing thorough climatological inferences, the spatial coverage encompassing the whole Italian Adriatic coast allows to assess geographical variability in model skills.

\section{Model results post-processing}

With reference to both CTR and SCE datasets, we considered the zonal and meridional components of the wind velocity at $10 \mathrm{~m}$ height, referred to local values at the coastal observa-

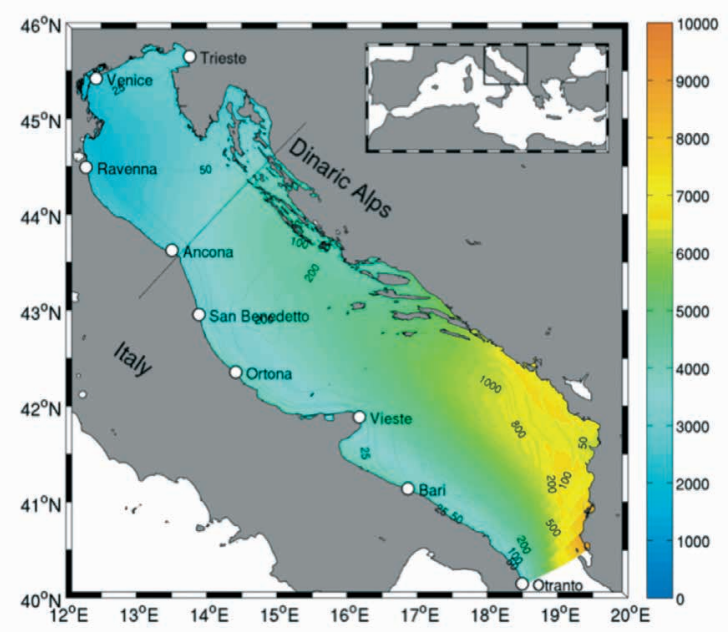

Fig. 1. Adriatic Sea and its position in the Mediterranean region. Contours outline basin bathymetry, white dots indicate the position of the measurement stations and the colour scale represents the horizontal resolution of the wave model grid. The thin dotted line indicates the Ancona-Novalja transect, here taken as a conventional boundary between the Northern and Southern Adriatic basins

tories and spatially averaged over the Northern Adriatic (NA, north of the Ancona-Novalja transect, see CARNIEL et al., 2016; Fig. 1) and Southern Adriatic (SA) basins, and on the whole Adriatic (WA) Sea. For each subdomain we considered the specific kinetic energy of the wind $\left(e_{k}\right)$ in the lower layers of the atmosphere potentially available for wave generation (USACE, 2002). This quantity was used instead of the significant wave height $H_{S}$ to characterise a priori (namely, without relying on wave model results) the storm events, following the procedure suggested by

Table 1. Measurement stations along the Italian Adriatic coast

\begin{tabular}{|l|l|c|}
\hline Name & Coordinates (Lon-Lat) & Period \\
\hline TRIESTE & $13^{\circ} 45^{\prime} 28.58^{\prime \prime}-45^{\circ} 38^{\prime} 57.81^{\prime \prime}$ & $01 / 01 / 2010-31 / 12 / 2015$ \\
\hline VENICE & $12^{\circ} 25^{\prime} 35.50^{\prime \prime}-45^{\circ} 25^{\prime} 05.59^{\prime}$ & $01 / 01 / 2010-31 / 12 / 2015$ \\
\hline RAVENNA & $12^{\circ} 16^{\prime} 58.57^{\prime}-44^{\circ} 29^{\prime} 31.47^{\prime}$ & $01 / 01 / 2010-31 / 12 / 2015$ \\
\hline ANCONA & $13^{\circ} 30^{\prime} 23.46^{\prime \prime}-43^{\circ} 37^{\prime} 29.16^{\prime \prime}$ & $01 / 01 / 2010-31 / 12 / 2014$ \\
\hline SAN BENEDETTO & $13^{\circ} 53^{\prime} 23.13^{\prime \prime}-42^{\circ} 57^{\prime} 18.44^{\prime \prime}$ & $18 / 06 / 2010-18 / 06 / 2016$ \\
\hline ORTONA & $14^{\circ} 24^{\prime} 53.50^{\prime \prime}-42^{\circ} 21^{\prime} 21.24^{\prime \prime}$ & $01 / 01 / 2010-31 / 12 / 2015$ \\
\hline VIESTE & $16^{\circ} 10^{\prime} 37.24^{\prime \prime}-41^{\circ} 53^{\prime} 17.10^{\prime \prime}$ & $01 / 01 / 2010-31 / 12 / 2015$ \\
\hline BARI & $16^{\circ} 51^{\prime} 57.72^{\prime \prime}-41^{\circ} 08^{\prime} 24.74^{\prime \prime}$ & $01 / 01 / 2010-31 / 12 / 2014$ \\
\hline OTRANTO & $18^{\circ} 29^{\prime} 49.52^{\prime \prime}-40^{\circ} 08^{\prime} 49.74 ”$ & $01 / 01 / 2010-31 / 12 / 2015$ \\
\hline
\end{tabular}


BOCCOTTI (2000). This approach prescribes the identification of the events in which $e_{k}$ exceeds a threshold (prescribed as 1.5 times its time-averaged value), the aggregation of events parted by less than 10 hours for ensuring stochastic independency, and the removal of the events lasting less than 12 hours. Each storm was thus characterised in terms of duration and a Kinetic Energy Index (KEI) computed by integrating over time the wind power per unit mass and area during the event, namely:

$$
K E I=0.5 \int_{t_{1}}^{t_{2}} U V^{3} d t
$$

where $U V$ is the wind speed and $t_{1}$ and $t_{2}$ represent the start and the end of a storm. The KEI provides an indication of the overall wind energy acting at a given location during a storm, and it has been used in the computation of the return period (namely, the inverse of the probability that an event with given intensity is equaled or exceeded in one year) of each event.

For each considered measurement site and based on the whole time series, we calculated observed and modelled monthly climatological averages and standard deviations of the wind specific kinetic energy, discriminating among four quadrants of wind origin. This allowed an evaluation of the model performances and a bulk assessment of the wind energy trend. Spatial patterns of the statistics of modelled quantities have been explored by computing, on each grid point, both the relevant percentiles of the wind speed considered within the whole time series, and the values corresponding to different return periods of the storm events. By averaging the information over the different subdomains and considering different months, climatological information about the the seasonal variability of the frequency and intensity of the modelled events were extracted. In order to explore the representativeness of the identification of potential storms based on the wind speed, we applied again the method proposed by Boccotti to the spatiallyaveraged significant wave heights retrieved from the SWAN runs. For each event an overall Wave storm Energy Index was computed as

$$
W E I=\int_{t_{1}}^{t_{2}} H_{S}^{2} T_{m-10} d t
$$

where $T_{m-10}$ represents the spectral energy period, $H_{s}$ is the significant wave height. Then we compared the return period of any wave storm with the return period of its generating wind event, if classified as a storm.

\section{RESULTS AND DISCUSSION}

\section{CTR run validation}

With respect to wind energy, model results exhibit a generally fair capability of reproducing mean values and variability (Fig. 2), together with the seasonal fluctuations of these quantities (Fig. 3), although with an overestimation in the monthly average and in the seasonal variability. In this, it is also worth noting that some information on the instruments installation is not fully complete, allowing some uncertainty on the evaluation of the retrieved data. The agreement of the directional variability and the identification of dominant winds is significantly enhanced compared to data sets resulting from previous numerical experiments (see BELLAFIORE et al., 2012), although some shortcomings still arise in the presence of complex geometries and immediately downstream of orographic features. This is for instance the case of the Trieste station, where the model representation of the coastal mountain ridge morphology can locally jeopard-
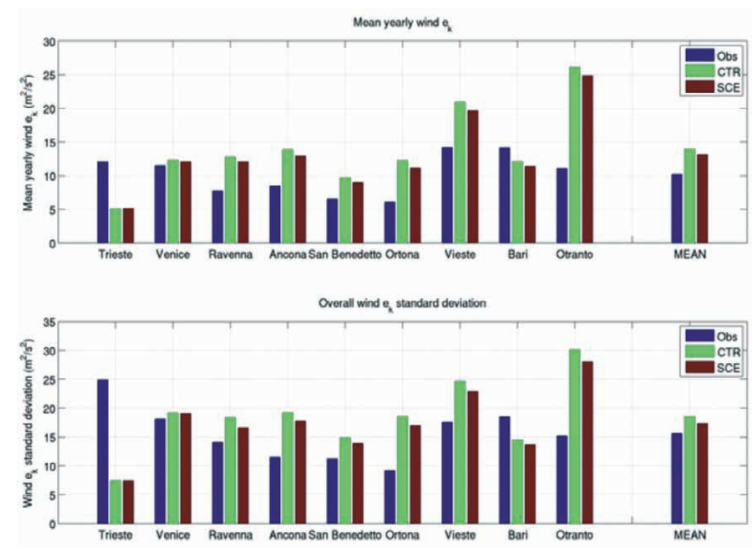

Fig. 2. Overview of observed and modelled mean (top) and standard deviation (bottom) wind specific kinetic energy at the measurement stations. 

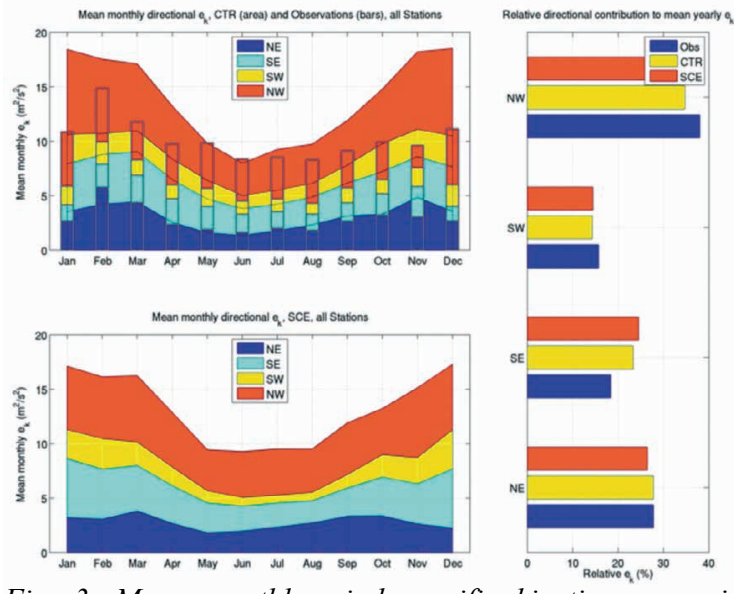

Fig. 3. Mean monthly wind specific kinetic energy in observed data (top left, bars), CTR (top left, area) andSCE (bottom left). The relative directional contribution is graphically depicted by the coloured areas and summarised over a yearly basis in the bar graph on the right-hand panel.

ize the description of patterns and intensity Bora jets intrusion from the orographic gaps (CARNIEL et al., 2009; HORVATH et al., 2011; CARNIEL et al., 2016). On the other hand, the dominance of Bora and Sirocco in the NA is clearly established downstream at Venice station. The capability of reproducing realistic spatial patterns of wind is exemplified by considering two instantaneous wind fields referred to different intense events depicted in Fig. 4. The left panel, referred to a typical Bora condition, shows (up to our knowledge, for the first time at this degree of

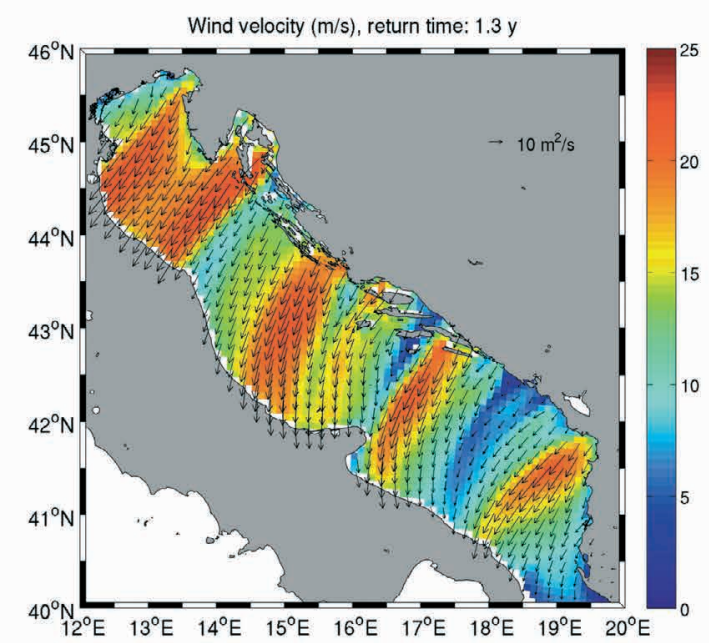

definition in a climatological model) the wellknown multiple jet system from the Dinarides (see KUZMIĆ et al., 2013; RICCHI et al., 2016). The right panel shows the configuration known as "dark Bora" (PASARIĆ et al., 2009), dominated by Sirocco eventually and rotating in the northern basin, giving rise to strong, humid northeasterly winds along the Italian coasts.

Overall, mean wind specific kinetic energy $e_{k}$ in the CTR run exceeds by approximately $36 \%$ the values from the observed time series, this overestimation being mostly concentrated in the central and southern Adriatic basin stations and in winter months (October to March). Although still presenting room for desirable improvements, it is worth noting that this performance represents a significant improvement compared to previous recent results (BELLAFIORE et al., 2012).

Fairly satisfactory performances are obtained in terms of storminess characterisation (Table 2) in which, although with a $15 \%$ underestimate of the occurrence frequency by the model, the directional distribution of the storms is generally well captured.

\section{Wind climate projections in the Adriatic Sea}

Accordingly with estimates from previous studies (LIONELLO et al., 2008; BENETAZZO et al.,

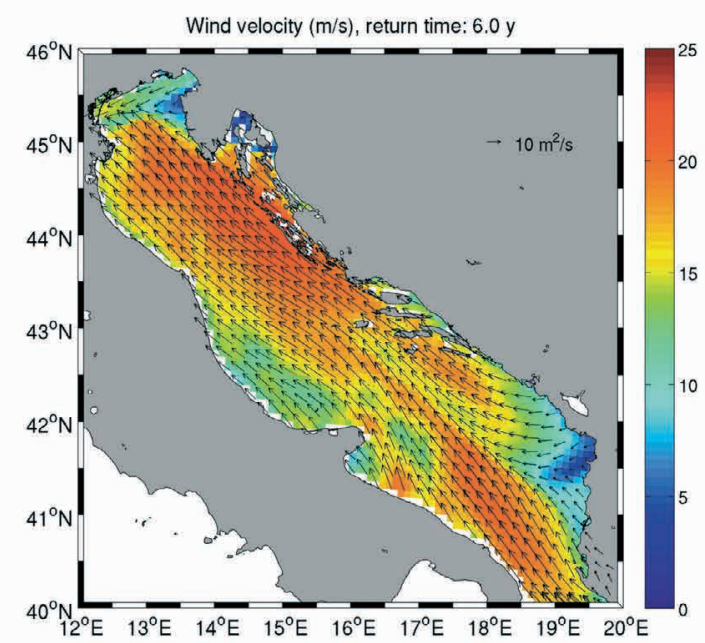

Fig. 4. Extreme events showing some typical wind patterns of the Adriatic Sea, namely Bora jets (left panel) and Sirocco (right). In the latter case it is worth noting the rotation of the wind field in the north, giving rise to the configuration known as "dark Bora" 
Table 2. Observed and modelled wind storms at the measurements sites, mean yearly occurrence and percent directional distribution. Storms were identified as the events in which the specific kinetic energy exceeds 1.5 times its timeaveraged value for a given location, aggregating events parted by less than 10 hours and removing the events shorter than 12 hours

\begin{tabular}{|lccccccc|}
\cline { 2 - 7 } \multicolumn{1}{c}{} & \multicolumn{3}{c}{ OVERALL } & \multicolumn{4}{c|}{ EXTREME } \\
\hline & $\underline{\text { Detection \% }}$ & $\underline{\mathrm{p}}$ & $\underline{\mathrm{S}}$ & $\underline{\text { Detection \% }}$ & $\underline{\mathrm{p}}$ & $\underline{\mathrm{S}}$ \\
\hline \multirow{4}{*}{ Bora } & 75 & 2.27 & 1.21 & 83 & 2.26 & 7.47 \\
Sirocco & 58 & 0.18 & 0.22 & 67 & 0.16 & 0.68 \\
All & 66 & 0.85 & 1.10 & 73 & 0.83 & 6.63 \\
Bora & 74 & 2.26 & 0.30 & 67 & 2.36 & 2.53 \\
Sirocco & 86 & 0.62 & 1.37 & 94 & 0.61 & 6.86 \\
All & 78 & 0.47 & 1.04 & 90 & 0.46 & 6.34 \\
Bora & 72 & 2.57 & 0.42 & 75 & 2.84 & 4.06 \\
Sirocco & 84 & 0.36 & 1.59 & 94 & 0.35 & 7.55 \\
All & 76 & 0.38 & 1.32 & 90 & 0.36 & 6.59 \\
\hline
\end{tabular}

2012), climatological projections tend to suggest a tendency towards an overall wind energy decrease in the lowermost levels of the atmosphere at the observation sites (Fig. 3). In fact, considering the broader picture of the whole Adriatic basin and its mainland, a more heterogeneous scenario arises in the expected variations of the energetic conditions. Fig. 5 shows that wind speed asso-
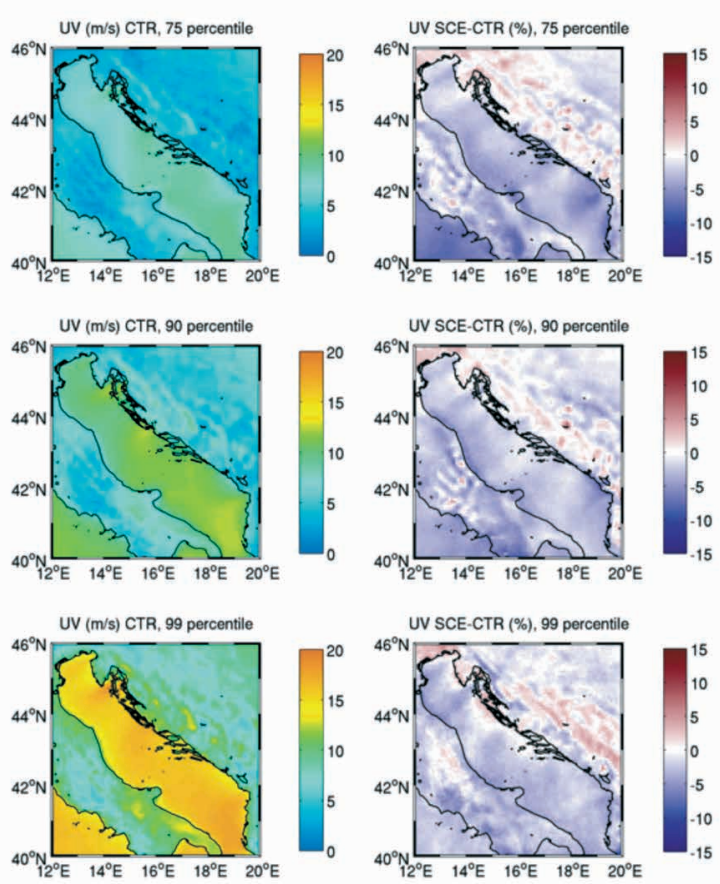

Fig. 5. Patterns of modelled wind velocity corresponding to 75 (top), 90 (middle) and 99 (bottom) percentiles in the CTR run (left) and percent variation in the RCP8.5 scenario (right) ciated to moderate ( 75 percentile) to severe ( 99 percentile) conditions is actually expected to undergo a $0-10 \%$ decrease across the whole Adriatic Sea, although mostly with stronger decrease along the Bora jets patterns. On the other hand, in the mainland the variability is stronger, allowing the possibility of local increases especially nearby mountain ridges and in downstream regions. Considering the overall energy developed during a storm, Fig. 6 shows that in the Northern Adriatic the value of KEI is expected to decrease by $5 \%$ its control value for return periods up to one year and more than $10 \%$ for return periods

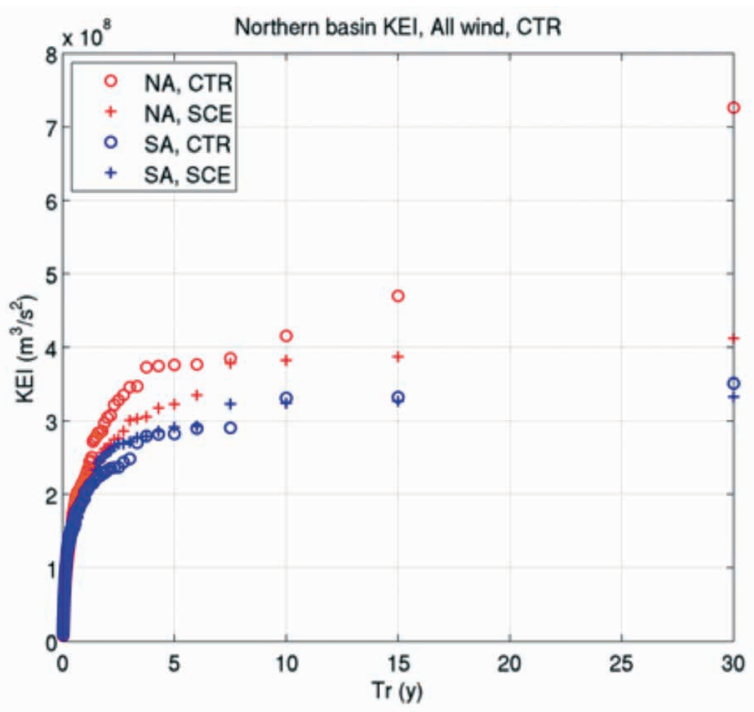

Fig. 6. Space-averaged Kinetic Energy Index associated wind storms with different return periods in CTR and SCE conditions 
above 5 years. In the southern basin the intensity of storms with return period greater than one year is generally smaller, and expected variations are very small as well, with the possibility of small increases between 1 and 10 years return period. The average number of storm episodes in the Northern Adriatic Sea in the CTR run is 39.5 events per year, almost invariant in SCE, associated with a $-8.2 \%$ decrease in the cumulative yearly value of KEI in the climate change scenario. In the face of this slight change in terms of overall energy amount potentially available for the generation of wave storms, model runs suggest a more significant modification in the directional distribution of wind episodes towards an adjustment of the relative energy contribution of Bora and Sirocco. In fact, cumulative yearly KEI associated with Bora episodes undergoes a $-29.3 \%$ decline, whereas the value of this parameter associated with Sirocco storms exhibits a $+22.2 \%$ increase. In the Southern Adriatic Sea, the number of storms is expected to remain nearly unchanged (from 46.3 to 46.6 events per year) with a $-4.5 \%$ decrease in terms of cumulative yearly KEI. Here, the energetic contribution of Bora storms is not as strong as in the northern basin, whereas Sirocco provides nearly $46 \%$ of the whole storm energy both in the CTR and in the SCE runs. Worth pointing out, while the indications of Bora and Sirocco KEI trends in the

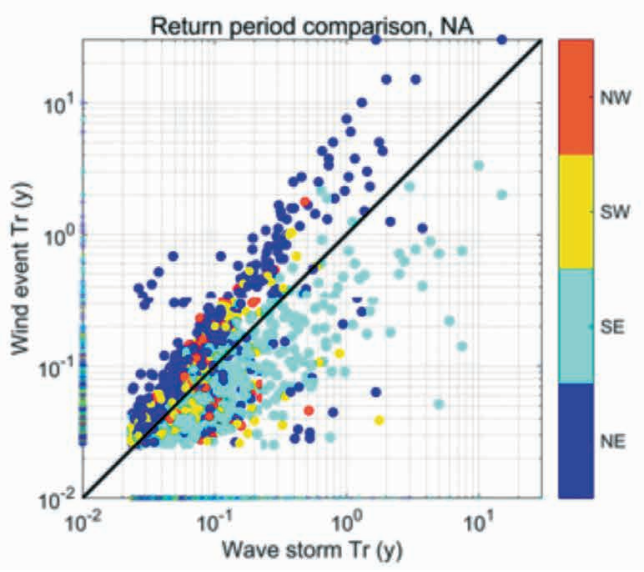

Northern Adriatic Sea are supported by a 95\% significance test, the estimates on storminess and KEI in the Southern basin should only be considered as orientative.

\section{Extreme wave storms identification from wind model data}

In the Fig. 7 authors provide an overview of the applicability of the wind KEI as a proxy for the identification of relevant events for oceanographic climatological simulations, based on both runs aggregated Table 3 summarizes the main statistical parameters of this relation for the different domains, providing the detection rate, the slope of best fit lines and the root mean square deviation of the distributions. Concerning the northern basin, wave events that were actually predicted by the Kinetic Energy parameter $(66 \%$ overall, and $73 \%$ of the events with return period equal or greater than 1 year) are clustered along two main trends. The return period of Sirocco-induced wave storms intensity is generally underestimated by the Kinetic Energy parameter. This, together with the relatively low detection rate $(58 \%$ in the whole dataset, $67 \%$ among the extreme events) is due to the fact that the features of swell sea states in the northern basin are the result of the action of Sirocco along the main axis of the basin, which is not always

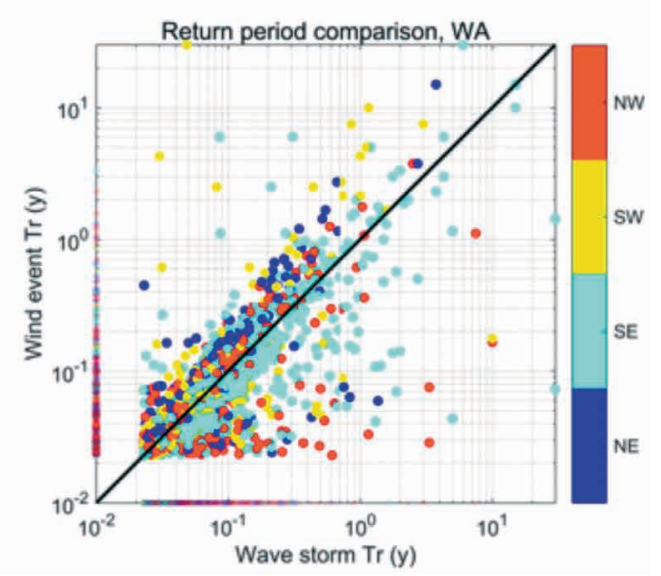

Fig. 7. Return period of wind events associated to wave storms in the Northern (left) and Whole (right) Adriatic Sea. For every wave storm event with a given return period along the $x$-axis, the corresponding value along the y-axis identifies the return period of the wind event responsible for that wave storm episode, and the colour represents the direction of the wind source. Points spread along the $x$ - and $y$-axes represent respectively the wave events whose generating wind conditions were not identified as storms, and wind events locally characterised as storms that did not give rise to a wave storm 
Table 3. Representativeness of the wind KEI proxy for the identification of storm events in different conditions. $p$ and $S$ are respectively the slope of the best fit lines of the wind and wave return periods and the associated root mean square deviation

\begin{tabular}{|c|c|c|c|c|c|c|}
\hline & & $\begin{array}{c}\text { Storms } \\
\text { per year }\end{array}$ & $\%$ NE & $\% \mathrm{SE}$ & $\begin{array}{r}\% \\
\text { SW }\end{array}$ & $\begin{array}{r}\% \\
\text { NW }\end{array}$ \\
\hline \multirow{2}{*}{ Trieste } & Obs & 35.86 & 86.38 & 11.27 & 0.00 & 2.35 \\
\hline & CTR & 33.67 & 66.63 & 22.57 & 10.59 & 0.20 \\
\hline \multirow{2}{*}{ Venice } & Obs & 39.84 & 71.97 & 14.23 & 10.04 & 3.77 \\
\hline & CTR & 33.40 & 64.17 & 18.56 & 10.78 & 6.49 \\
\hline \multirow{2}{*}{ Ravenna } & Obs & 42.18 & 35.97 & 42.69 & 5.14 & 16.21 \\
\hline & CTR & 33.40 & 47.41 & 23.05 & 16.67 & 12.87 \\
\hline \multirow{2}{*}{ Ancona } & Obs & 52.21 & 13.79 & 13.41 & 21.84 & 50.57 \\
\hline & CTR & 36.13 & 34.13 & 14.21 & 17.71 & 33.95 \\
\hline \multirow{2}{*}{ San Benedetto } & Obs & 38.31 & 40.00 & 6.52 & 2.61 & 50.00 \\
\hline & CTR & 33.80 & 23.96 & 11.44 & 7.00 & 57.59 \\
\hline \multirow{2}{*}{ Ortona } & Obs & 41.84 & 15.94 & 4.38 & 34.66 & 45.02 \\
\hline & CTR & 35.90 & 9.10 & 13.09 & 9.75 & 68.06 \\
\hline \multirow{2}{*}{ Vieste } & Obs & 48.18 & 6.92 & 14.53 & 9.34 & 69.20 \\
\hline & CTR & 42.60 & 6.57 & 25.04 & 7.82 & 60.56 \\
\hline \multirow{2}{*}{ Bari } & Obs & 46.21 & 3.03 & 19.48 & 6.93 & 70.56 \\
\hline & CTR & 36.57 & 6.84 & 22.88 & 11.49 & 58.80 \\
\hline \multirow{2}{*}{ Otranto } & Obs & 44.51 & 11.61 & 10.86 & 8.99 & 67.42 \\
\hline & CTR & 45.50 & 7.84 & 46.52 & 6.74 & 38.90 \\
\hline
\end{tabular}

fully described by local wind conditions. Indeed, the detection rate for Sirocco increases significantly when considering the whole basin in the analysis ( $84 \%$ overall, $94 \%$ for extreme events), although with some underestimation. Bora detection rate, in turn, is more satisfactory in the north ( $75 \%$ overall, $83 \%$ among the extreme events), but in this case the sea state severity tends to be overestimated, presumably due to the fact that the sea state development is fetch-limited. In the southern basin, where the dominance of Bora and Sirocco is less important, this behaviour is not as much evident, but the detection rate and the fitting parameters are still on the same order of magnitude and variability.

\section{CONCLUSIONS}

Together with sea level rise, and in some cases even more effectively, wave climate modifications can be the main threat for coastal stability, especially in the case of moderate- to high-energy sandy coasts (MORTLOCK \& GOOD-
WIN, 2015). The capability of capturing wind climate variability over a decadal time scale is crucial for providing a realistic quantification of wave dynamics and coastal sediment transport processes (CARNIEL et al., 2011; ALMAR et al., 2015; BONALDO et al., 2015), identifying possible erosional and depositional hotspots and setting intervention priorities for coastal management. This is particularly relevant in the case of semienclosed seas such as the Adriatic Sea or the Baltic Sea, in which waves, currents and sediment transport patterns are strongly controlled by the relationship between basin geometry and variations in wind intensity and direction (SCLAVO et al., 2013; SOOMERE \& VIŠKA, 2014; SOOMERE et al., 2015). In this work we assessed modelled COSMO-CLM wind climate data over the Adriatic Sea at $8 \mathrm{~km}$ horizontal resolution under the high-emission IPCC RCP8.5 scenario. Furthermore, we explored the possibility and limitations of using wind model data for identifying storm events of particular relevance for coastal protection on which to concentrate wave modelling 
efforts, possibly with an ensemble approach. Due to the temporal span of the observational dataset considered in this study, the comparison with the model results should be considered as an overall evaluation of the model performances instead of a thorough climatological validation. In turn, benefiting from to the spatial coverage of the dataset, the results of this evaluation can be specified along the whole axis of the Adriatic Sea, to some extent compensating the limitations of the time series length.

With this caveat in mind, the results of this work allow to integrate meteo-oceanographic projections for the Adriatic Sea with some relevant practical implications. Besides providing a quite satisfactory description of climatological wind fields, COSMO-CLM exhibits a remarkable capability of replicating wind directionality and sharp spatial gradients. This skill is generally rather uncommon in climatological models, although particularly important for an appropriate description of processes dominated by kinetic energy and heat exchanges between atmosphere and ocean. For this reason, COSMO-CLM represents a wealthy potential for a broad set of climatological oceanographic applications, from dense water production and thermohaline circulation to the description of wave climate and the likely threats for coastal morphological stability. The decreasing trend of storminess in the Adriatic Sea predicted by several models in moderate to severe emission scenarios (BELLAFIORE et al., 2012; BENETAZZO et al., 2012) is here confirmed, on average, with reference to the IPCC RCP8.5 scenario. Although the decrease of yearly number of storm events is not generally statistically significant, the energetic trend seems more defined especially in the northern basin, consolidating the established relationship between global changes induced by intense carbon dioxide production and local climatological effects in this area.

In the case that the computational requirements are the limiting factor for oceanographic applications, our verification of the representativeness of wind KEI as a proxy for identifying potential storms allows to focus climatological evaluation on some extreme events, though with some caution to the definition of the spatial domain based on the events to be considered. The detection rate is generally satisfactory when the identification of events potentially leading to severe sea state for a given wind is performed on a basin in which this wind blows with reasonably uniform intensity. This is indeed the case of Bora in the northern Adriatic Sea and of Sirocco in the whole basin. On the other hand, although a general character of "extreme" intensity is captured for the most part, the return period of modelled wind events is generally not precisely representative of the sea state generated under those conditions. For this reason, a climatological study of extreme storms identified based on a metric of the wind kinetic energy should presently consider a suitable number of cases in order to properly compensate the uncertainties related with the use of this proxy.

\section{ACKNOWLEDGEMENTS}

This work was supported by the Flagship Project RITMARE - The Italian Research for the Sea (coordinated by the Italian National Research Council and funded by the Italian Ministry of Education, University and Research within the National Research Program 2011-2013) and by the UE H2020 program under grant agreement No. 730030 (CEASELESS Project, Coordinator Agustin SANCHEZ-ARCILLA).

\section{REFERENCES}

ACCIARRI, A., C. BISCI, G. CANTALAMESSA \& G. DI PANCRAZIO. 2016. Anthropogenic influence on recent evolution of shorelines between the Conero Mt. and the Tronto R. mouth (southern Marche, Central Italy). CATENA 147, 545-555. doi:10.1016/j.catena.2016.08.018
ALMAR, R., E. KESTENARE, J. REYNS, J. JOUANNO, E.J. ANTHONY, R. LAIBI, M. HEMER, Y. DU PENHOAT \& R. RANASHINGE. 2015. Response of the Bight of Benin (Gulf of Guinea, West Africa) coastline to anthropogenic and natural forcing, Part 1: Wave climate vari- 
ability and impacts on the longshore sediment transport. Continental Shelf Research, 110:48-59.

ANTONIOLI, F., M. ANZIDEI, A. AMOROSI, V. LO PRESTI, G. MASTRONUZZI, G. DEIANA, G. DE FALCO, G. FONTOLAN, A. FONTANA, S. LISCO, A. MARSICO, M. MORETTI, P. ORRU, G.M. SANNINO, E. SERPELLONI \& A. VECCHIO. 2017. Sea flooding scenario at four Italian coastal plains for 2100. Quaternary Science Reviews 158, 29-43.

BELLAFIORE, D., E. BUCCHIGNANI, S. GUALDI, S. CARNIEL, V. DJURDJEVIĆ, \& G. UMGIESSER. 2012. Assessment of meteorological climate models as inputs for coastal studies. Ocean Dyn. 62, 555-568. doi:10.1007/s10236-0110508-2

BENETAZZO, A., F. FEDELE, S. CARNIEL, A. RICCHI, E. BUCCHIGNANI \& M. SCLAVO. 2012. Wave climate of the Adriatic Sea: A future scenario simulation. Nat. Hazards Earth Syst. Sci. 12, 2065-2076. doi:10.5194/nhess-122065-2012

BENETAZZO, A., S. CARNIEL \& M. SCLAVO, A. BERGAMASCO. 2013. Wave-current interaction: Effect on the wave field in a semienclosed basin. Ocean Model. 70, 152-165. doi:10.1016/j.ocemod.2012.12.009

BENETAZZO, A., A. BERGAMASCO, D. BONALDO, F.M. FALCIERI, M. SCLAVO, L. LANGONE \& S. CARNIEL. 2014. Response of the Adriatic Sea to an intense cold air outbreak: Dense water dynamics and wave-induced transport. Prog. Oceanogr. 128, 115-138. doi:10.1016/j.pocean.2014.08.015

BENSI, M., V. CARDIN, A. RUBINO, G. NOTARSTEFANO \& P.M. POULAIN. 2013. Effects of winter convection on the deep layer of the Southern Adriatic Sea in 2012. J. Geophys. Res. Ocean. 118, 1-12. doi:10.1002/2013JC009432

BOCCOTTI, P. 2000. Wave Mechanics for Ocean Engineering. Elsevier Science, Oxford.

BONALDO, D., A. BENETAZZO, M. SCLAVO \& S. CARNIEL. 2015. Modelling wave-driven sediment transport in a changing climate: a case study for northern Adriatic Sea (Italy). Reg. Environ. Chang. 15, 45-55. doi:10.1007/ s10113-014-0619-7

BONALDO, D., A. BENETAZZO, A. BERGAMASCO,
E. CAMPIANI, F. FOGLINI, M. SCLAVO, F. TRINCARDI \& S. CARNIEL. 2016. Interactions among Adriatic continental margin morphology, deep circulation and bedform patterns. Mar. Geol. 375, 82-98. doi:10.1016/j. margeo.2015.09.012

BOOIJ, N., R.C. RIS \& L.H. HOLTHUIJSEN. 1999. A third-generation wave model for coastal regions 1 . Model description and validation 104, 7649-7666.

BUCCHIGNANI, E., M. MONTESARCHIO, A.L. ZOLLO \& P. MERCOGLIANO. 2016. High-resolution climate simulations with COSMOCLM over Italy: Performance evaluation and climate projections for the 21 st century. Int. J. Climatol. 36(2):735-756. doi:10.1002/ joc. 4379

CANALS, M., P. PUIG, X.D. DE MADRON, S. HEUSSNER, A. PALANQUES \& J. FABRES. 2006. Flushing submarine canyons. Nature 444, 354-357.

CARNIEL, S., J. WARNER, J. CHIGGIATO \& M. SCLAVO. 2009. Investigating the impact of surface wave breaking on modelling the trajectories of drifters in the Northern Adriatic Sea during a wind-storm event. Ocean Model. 225239. doi:10.1016/j.ocemod.2009.07.001

CARNIEL S., M. SCLAVO \& R. ARCHETTI, 2011. Towards validating a last generation, integrated wave-current-sediment numerical model in coastal regions using video measurements. Oceanological and Hydrobiological Studies, 40(4), 11-20. doi: 10.2478/ s13545-011-0036-1

CARNIEL, S., A. BENETAZZO, D. BONALDO, F. M. FALCIERI, M.M. MIGLIETTA, A. RICCHI \& M. SCLAVO. 2016. Scratching beneath the surface while coupling atmosphere, ocean and waves: Analysis of a dense water formation event. Ocean Model. 101, 101-112. doi:10.1016/j.ocemod.2016.03.007

CAVALERI, L., L. BERTOTTI \& P. LIONELLO. 1989. Wind-waves evaluation in the Adriatic and Mediterranean Seas. International Journal for Numerical Methods in Engineering, 27, 57-69.

CHINI, N. \& P.K. STANSBY. 2012. Extreme values of coastal wave overtopping accounting for 
climate change and sea level rise. Coast. Eng. 65, 27-37.

CHRISTENSEN, J.H. \& O.B. CHRISTENSEN. 2007. A summary of the PRUDENCE model projections of change in European climate by the end of this century, Climatic Change 81: 7-30. doi: 10.1007/s10584-006-9210-7

CONTE, D. \& P. LIONELLO. 2014. Storm surge distribution along the Mediterranean coast: Characteristics and evolution. $3^{\text {rd }}$ Int. Geogr. Symp. Geomed 2013 120, 110-115. doi:10.1016/j.sbspro.2014.02.087

DJURDJEVIĆ, V. \& B. RAJKOVIĆ. 2010. Development of the EBU-POM coupled regional climate model and results from climate change experiments. Nova, New York.

FOGLINI, F., E. CAMPIANI \& F. TRINCARDI. 2016. The reshaping of the South West Adriatic Margin by cascading of dense shelf waters. Mar. Geol. 375, 64-81.

GIORGI, F., X. BI \& J. PAL. 2004. Mean interannual variability and trends in a regional climate change experiment over Europe. Clim Dyn 22:733-756

HORVATH, K., A. BAJIĆ \& S. IVATEK-ŠAHDAN. 2011. Dynamical downscaling of wind speed in complex terrain prone to bora-type flows. J. Appl. Meteorol. Climatol. 50, 1676-1691. doi:10.1175/2011JAMC2638.1

HOLTHUIJSEN, L.H. 2010. Waves in Oceanic and Coastal waters, Cambridge University Press, ISBN 1139462520.

IVANOV, V.V., G.I. SHAPIRO, J.M. HUTHNANCE, D.L. ALEYNIK \& P.N. GOLOVIN. 2004. Cascades of dense water around the world ocean, Progress In Oceanography. doi:10.1016/j. pocean.2003.12.002

KILLWORTH, P.D. 1983. Deep convection in the world ocean. Rev. Geophys. Space Phys., 21: 1-26.

KUZMIĆ, M., X. LI, B. GRISOGONO, I. TOMAZIĆ \& S. LEHNER. 2013. TerraSAR-X observations of the northeastern Adriatic bora: Early results. Acta Adriat., 54: 13-26.

LIONELLO, P. S. COGO, M.B. GALATI \& A. SANNA. 2008. The Mediterranean surface wave climate inferred from future scenario simulations. Glob. Planet. Change 63, 152-162. doi:10.1016/j.gloplacha.2008.03.004

MIHANOVIĆ, H.; I. VILIBIĆ, S. CARNIEL, M. TUDOR, A. RUSSO, A. BERGAMASCO, N. BUBIĆ, Z. LJUBEŠIIĆ, D. VILIČIĆ, A. BOLDRIN, V. MALAČIĆ, M. CELIO, C. COMICI \& F. RAICICH. 2013. Exceptional dense water formation on the Adriatic shelf in the winter of 2012. Ocean Sci. 9, 561-572. doi:10.5194/os-9-561-2013

MORTLOCK, T.R. \& I.D. GOODWIN. 2015. Directional wave climate and power variability along the Southeast Australian shelf. Cont. Shelf Res. 98, 36-53. doi:10.1016/j. csr.2015.02.007

MOSS, R. J. EDMONDS, K. HIBBARD, M. MANNING., S. ROSE, D.P. VAN VUUREN, T. CARTER, S. EMORI, M. KAINUMA, T. KRAM, G. MEEHL, J. MITCHELL, N. NAKICENOVIC, K. RIAHI, S. SMITH, R. STOUFFER, A. THOMSON, J. WEYANT \& T. WILBANKS. 2010. The next generation of scenarios for climate change research and assessment, Nature 463: 747- 756. doi:10.1038/nature08823

NELSON, B. 1970. Hydrography, sediment dispersal, and recent historical development of the Po River delta, Italy, in Deltaic Sedimentation Modern and Ancient, edited by J. P. Morgan and R. H. Shaver, Spec. Publ. Soc. Econ. Paleontol. Mineral., 15, 152-184.

NICHOLLS, R.J. 2011. Planning for the impacts of sea level rise. Oceanography $24,144-157$. doi:10.5670/oceanog.2011.34

ORLIĆ, M., M. KUZMIĆ \& Z. PASARIĆ. 1994. Response of the Adriatic Sea to the bora and sirocco forcing. Cont. Shelf Res. 14, 91-116.

PASARIĆ, Z., D. BELUŠIĆ \& J. CHIGGIATO. 2009. Orographic effects on meteorological fields over the Adriatic from different models. J. Mar. Syst. 78, 90-100. doi:10.1016/j. jmarsys.2009.01.019

RICCHI, A. M.M. MIGLIETTA, P.P. FALCO, A. BENETAZZO, D. BONALDO, A. BERGAMASCO, M. SCLAVO \& S. CARNIEL. 2016. On the use of a coupled ocean-atmosphere-wave model during an extreme Cold Air Outbreak over the Adriatic Sea. Atmos. Res. 172-173, 48-65. doi:10.1016/j.atmosres.2015.12.023

ROCKEL, B., A. WILL \& A. HENSE. 2008. The region- 
al Climate Model COSMO-CLM (CCLM). Meteorologische Zeitschrift 17: 347-348. doi: 10.1127/0941-2948/2008/0309

SCLAVO, M., A. BENETAZZO, S. CARNIEL, A. BERGAMASCO, F.M. FALCIERI \& D. BONALDO. 2013. Wave-current interaction effect on sediment dispersal in a shallow semi-enclosed basin. Journal of Coastal Research 65, 1587-1592. SCOCCIMARRO, E. S. GUALDI, A. BELLUCCI, A. SANNA, P. FOGLI, E. MANZINI, M. VICHI, P. ODDO \& A. NAVARRA. 2011. Effects of Tropical Cyclones on Ocean Heat Transport in a High Resolution Coupled General Circulation Model. Journal of Climate 24: 43684384. doi: 10.1175/2011JCLI4104.1

SIGNELL, R.P., S. CARNIEL, L. CAVALERI, J. CHIGGiato, J.D. DOYLE, J. PULlEN \& $\mathrm{M}$. SCLAVO. 2005. Assessment of wind quality for oceanographic modelling in semienclosed basins. J. Mar. Syst. 53, 217-233. doi:10.1016/j.jmarsys.2004.03.006

SLOTT, J.M., A.B. MURRAY, A.D. ASHTON \& T.J. CROWLEY. 2006. Coastline responses to changing storm patterns. Geophys. Res. Lett. 33, L18404.

SOOMERE, T. \& M. VIŠKA. 2014. Simulated wavedriven sediment transport along the eastern coast of the Baltic Sea. Journal of Marine Systems 129, 96-105.

SOOMERE, T., S.R. BISHOP, M. VIŠKA \& A. RÄÄMET. 2015. An abrupt change in winds that may radically affect the coasts and deep sections of the Baltic Sea. Climate Research, 62(2), 163-171.

STEPPELER, J., G. DOMS, U. SCHÄTTLER, H.W. BITZER, A. GASSMANN, U. DAMRATH \& G. GREGORIĆ. 2003. Meso-gamma scale forecasts using the nonhydrostatic model LM. Meteorology and Atmospheric Physics. 82:75-96. DOI: 10.1007/s00703-001-0592-9

SUPIĆ, N. \& M. ORLIĆ. 1999. Seasonal and interannual variability of the northern Adriatic surface fluxes. Journal of Marine Systems 20, 205-229.

TOL, R.S.J., R.J.T. KLEIN \& R.J. NICHOLLS. 2008.
Towards successful adaptation to sea-level rise along Europe's coasts. J. Coast. Res. 242, 432-442. doi:10.2112/07A-0016.

TORRESAN, S., A. CRITTO, J. RIZZI \& A. MARCOMINI. 2012. Assessment of coastal vulnerability to climate change hazards at the regional scale: the case study of the North Adriatic Sea. Nat. Hazards Earth Syst. Sci. 12, 2347-2368. doi:10.5194/nhess-12-23472012.

U.S. ARMY CORPS OF ENGINEERS (USACE). 2002. Coastal Engineering Manual. Engineer Manual 1110-2-1100, U.S. Army Corps of Engineers, Washington (in 6 volumes).

VAN MAANEN, B., R.J. NICHOLLS, J.R. FRENCH, A. BARKWITH, D. BONALDO, H. BURNINGHAM, B. MURRAY, A. PAYO, J. SUTHERLAND, G. TORNHILL, I.H. TOWNEND, M. VAN DER WEGEN \& M.J.A. WALKDEN. 2015. Simulating mesoscale coastal evolution for decadal coastal management: A new framework integrating multiple, complementary modelling approaches. Geomorphology. doi:10.1016/j. geomorph.2015.10.026

VACCHI, G.A. \& A.T. WITTEMBERG. 2010. El Niño and our future climate: Where do we stand? Wiley Interdiscip. Rev. Clim. Chang. 1: 260-270.

VILIBIĆ, I. \& N. SUPIĆ. 2005. Dense water generation on a shelf: the case of the Adriatic Sea. Ocean Dynamics 55, 403-415.

ZAMBON, J.B., R. HE \& J.C. WARNER. 2014. Investigation of hurricane Ivan using the coupled ocean-atmosphere-wave-sediment transport (COAWST) model. Ocean Dyn. 15351554. doi:10.1007/s10236-014-0777-7

ZOLLO, A.L., V. RILLO, E. BUCCHIGNANI, M. MONTESARCHIO \& P. MERCOGLIANO. 2016. Extreme temperature and precipitation events over Italy: assessment of high-resolution simulations with COSMO-CLM and future scenarios. Int. J. Climatol. , 36(2):987-1005 doi:10.1002/joc.4401

Received: 9 March 2017

Accepted: 11 July 2017 


\title{
Utjecaj olujnog vjetra na Jadransko more u uvjetima klimatskih promjena
}

\author{
Davide BONALDO*, Edoardo BUCCHIGNANI, Antonio RICCHI i Sandro CARNIEL \\ *Kontakt e-adresa: davide.bonaldo@ve.ismar.cnr.it
}

\begin{abstract}
SAŽETAK
U ovom radu ocjenjujemo kvalitetu polja vjetra nad Jadranskim morem dobivenog primjenom Regionalnog klimatskog modela COSMO-CLM za kontrolno razdoblje (CTR) od 1971. do 2000. i za buduće razdoblje od 2071. do 2100. uz pretpostavku klimatskog scenarija IPCC RCP 8.5 (SCE), s posebnim osvrtom na posljedice za valnu klimu.

Kvaliteta modela procijenjena je usporedbom njegovih rezultata za CTR-a s podacima vjetra $\mathrm{s}$ obalnih opservatorija duž cijelog talijanskog dijela jadranske obale na temelju ukupnih statističkih i olujnih svojstava. Usporedba je pokazala zadovoljavajuće rezultate modela pri reproduciranju glavnih obilježja srednje opažene sezonske varijabilnosti.

Značajna unapređenja u odnosu na postojeće klimatske modele dobivena su posebice u reproduciranju smjera vjetra, kao i pri uspješnoj reprodukciji bimodalne dominacije bure (sa sjeveroistoka) $\mathrm{i}$ juga (s jugoistoka) u sjevernom bazenu, te tipičnim obrascima bure s jakim intenzitetima ispred planinskih prijevoja duž istočne obale Jadranskoga mora.

Buduće projekcije općenito potvrđuju negativni trend energije predviđen i prethodnim studijama, $\mathrm{s}$ izrazitijim učinkom na ekstremne događaje u sjevernom bazenu.

$\mathrm{Na}$ temelju usporedbe klimatoloških valnih polja i rezultata valnog modela SWAN forsiranog izlaznim poljima COSMO-CLM modela, definirani i testirani su kriteriji za brzu identifikaciju relevantnih situacija u modeliranju valova bez potrebe za izvođenjem cijele klimatološke simulacije valova. To dozvoljava da se analiza klimatoloških oceanografskih ekstremnih događaja usredotoči na ograničeni broj odabranih slučajeva, čime se omogućava značajna ušteda računalnih resursa pogotovo ako se želi primjeniti ansambl modela.
\end{abstract}

Ključne riječi: klima vjetra, klimatološko modeliranje, ulazni podaci za modeliranje valova 